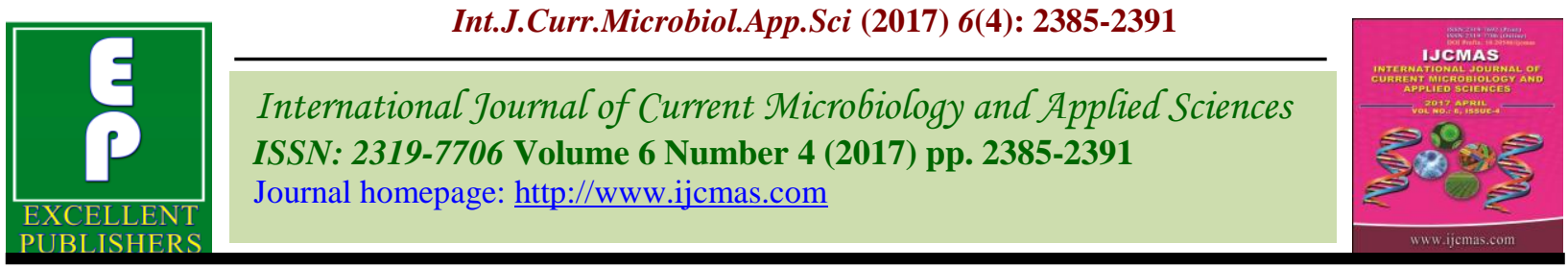

Review Article

https://doi.org/10.20546/ijcmas.2017.604.278

\title{
Coriander a Potential Seed Spice Crop of Humid South Eastern Plains-Zone of Rajasthan, India
}

\author{
R.K. Bairwa ${ }^{1 *}$, B.L. Dhaka ${ }^{1}$, M.K. Poonia ${ }^{2}$, B.L. Nagar ${ }^{3}$ and C.M. Balai ${ }^{4}$ \\ ${ }^{1}$ Krishi Vigyan Kendra, Bundi (Rajasthan) 323 001, India \\ ${ }^{2}$ Krishi Vigyan Kendra, Kota (Rajasthan) 324 001, India \\ ${ }^{3}$ Agriculture Research Station, Kota (Rajasthan) 324 001, India \\ ${ }^{4}$ Krishi Vigyan Kendra, Dungarpur (Rajasthan) 314001, India \\ *Corresponding author
}

\begin{tabular}{|c|c|}
\hline & A B S T R A C T \\
\hline $\begin{array}{l}\text { Coriander, } \\
\text { Properties, } \\
\text { Cultivation, } \\
\text { Productivity }\end{array}$ & \multirow{3}{*}{$\begin{array}{l}\text { Coriander is an annual seed spice crop, which belongs to family Apiaceae. It is native of } \\
\text { Mediterranean region. The aromatic characters of plants are due to presence of linalool } \\
\text { compound in essential oil of seeds. The green leaves of coriander are used in salads and } \\
\text { are a good source of vitamin A and vitamin C. Major active constituents of coriander } \\
\text { essential oils and fatty oil. The essential oil content of the weight of ripe and a dried fruit } \\
\text { of coriander varies between } 0.03 \text { and } 2.6 \% \text { and the content of fatty oil varies between } 9.9 \\
\text { and } 27.7 \% \text {. Coriander leave showed stronger antioxidant activity than the seeds. Coriander } \\
\text { lowered the blood sugar when added to the diet of diabetic patients. The } \\
\text { antihyperglycemic action of coriander is associated with stimulation of insulin secretion } \\
\text { and enhancement of glucose uptake and metabolism by muscle, reflecting the effects of } \\
\text { more than one active constituent. }\end{array}$} \\
\hline Article Info & \\
\hline $\begin{array}{l}\text { Accepted: } \\
20 \text { March } 2017 \\
\text { Available Online: } \\
10 \text { April } 2017\end{array}$ & \\
\hline
\end{tabular}

\section{Introduction}

Rajasthan is the largest coriander producing state in India and contribute $62 \%$ of India's total production. It is mainly grown in Hadoti region of Rajasthan comprising of Kota, Bundi, Baran and Jhalawar districts and holds the entire production in Rajasthan. However, the productivity of coriander is low compare to its potential yield. Farmers are facing numerous problems in realizing the full production potential of coriander. It is realized that lack of suitable high yielding variety as well as poor knowledge of improved production technologies along with complex disease-pest syndrome, emergence of new biotypes and races of key pests and pathogens are major impediments in realizing the full potentialities of coriander production. With the development of high yielding, early maturing, fertilizer responsive varieties are a new proposition which would ensure stability and higher profit per unit area of land and has potential to produce $20-25 \%$ higher seed yield than other existing varieties (Nagar et al., 2009).

Coriander (Coriandrum sativum L.) is an annual seed spice crop, which belongs to family Apiaceae. It is native of Mediterranean region. The aromatic characters of plants are due to presence of linolool compound in 
essential oil of seeds. The green leaves of coriander are used in salads and are a good source of vitamin $A$ and vitamin $C$. The young plant leaves as well as the seed are used for the preparation of chutney and are also used as seasoning in curries, soup, sauces, fish sauce and cream sauce for chicken etc (Janardhan and Thoppil, 2004; Tiwary and Agarwal, 2004). Besides their use in culinary, the seeds and leaves are also used for the treatment of maladies like indigestion, dyspepsia, flatulence and piles (Dimri et al., 1976).

\section{Botanical description}

Coriander leaves are small herb having many branches and sub-branches. New leaves are oval but aerial leaves are elongated. Flowers are white, having slightly brinjal like shades while fruit are round in shape (Handa and Kaul, 1996). Macroscopic characteristic of fruit is globular, mericarps usually united by their margins forming a cremocarp about 2-4 $\mathrm{mm}$ in diameter, uniformly brownish-yellow or brown, glabrous, sometimes crowned by then remains of sepals and styles, primary ridges 10 , wavy and slightly inconspicuous secondary ridges 8 , straight, it has aromatic odour. It has spicy and characteristic taste (Handa and Kaul, 1996; Pathak et al., 2011).

\section{Phytochemicals}

The general chemical composition present in coriander fruits are described in table 1 . Major active constituents of coriandrum sativum are essential oils and fatty oil. The essential oil content of the weight of ripe and dried fruits of coriander varies between 0.03 and $2.6 \%$ and the content of fatty oil varies between 9.9 and $27.7 \%, 1 \%$ of the major component of which is $\mathrm{S}-(+)-$ linalool (60$70 \%$ ) other minor active constituents present in essential oil are monoterpenes hydrocarbons viz. $\alpha$-pinene, limpnene, $\gamma$ - terpinene, p-cymene, borneol, citronellol, camphor, geraniol and geraniol acetate, heterocyclic components like pyrazine, pyridine thiazole, furan and tetrahudrofuran derivatives, isocoumarins, coriandrin, dihydrocoriandrin, coriandronsA-E, flavonoids, pthlides, neochidilide, digustilide phenolic acids and sterols. The composition of the essential oil is described in table 2 (Diederichsen, 1996; Pathak et al., 2011).

\section{Medicinal and pharmacological properties}

Coriander, due to its rich aroma because of its essential oils, apart from being an excellent appetizer, helps in proper secretion of enzymes and digestive juices in the stomach, stimulates digestion and peristaltic motion. It is helpful in treating problems like anorexia. Some of the components of essential oils in coriander such as borneol and linalool, aid digestion, proper functioning of liver and bonding of bowels and help to cure diarrhea. It is also helpful to treat diarrhea caused by microbial and fungal action, since components like cineole, borneol, limonene, alpha-pinene and betephelandrene have antibacterial effects. In addition, the fresh coriander leaves are excellent appetizers. Citronelol, a component of essential oils in coriander, is an excellent antiseptic. In addition, other components have antimicrobial and healing effects which do not let wounds and ulcers in the mouth go worse. The aid healing up of ulcers and freshen up the breath. The essential oils in coriander are rich in antimicrobial, antioxidant, anti-infectious and detoxifying components and acids. The presence of vitamin $\mathrm{C}$ and iron strengthens the immune system too. These properties help, prevent and cure small pox. They also reduce the pain and have a soothing effect on pox patients. Coriander has lots of antioxidants, vitamin$\mathrm{A}, \mathrm{C}$ and minerals like phosphorus which prevents aging of eye, muscular degeneration 
and soothes eyes against stress. Coriander is a very good disinfectant and has antimicrobial properties which prevent the eyes from contagious diseases like conjunctivitis (Saxena and Rathore, 2016).

Coriander leave showed stronger antioxidant activity than the seeds. In a study cryogenic grinding technology is helpful in retention of flavour and medicinal properties of coriander irrespective of genotypes from diverse origin showed significantly increase in oleoresin content, total phenolic contents, flavonoids and antioxidant properties (Saxena et al., 2015)

Coriander lowered the blood sugar when added to the diet of diabetic mice. The antihyperglycemic action of coriander is associated with stimulation of insulin secretion and enhancement of glucose uptake and metabolism by muscle, reflecting the effects of more than one active constituent. Coriander therefore, represents a possible antihyperglycemic along the inner walls of the arteries and veins (Ertas et al., 2005) Coriander seed essential oil is effective against stored product beetle pests (Pascual and Villalobos, 2003). The essential oil of coriander showed significant inhibitory effects of on the mycelia growth and toxin produced by $A$. ochraceus (Basilico and Basilico, 1999). Essential oils from commercial samples of coriander were showed antibacterial, antifungal and antioxidant activities.

\section{Cultivation}

\section{Climate}

Although coriander is a tropical crop, it is successfully grown in a wide range of conditions. It requires a cool climate in the early stages of growth and warm dry weather at maturity. The best period for cultivation is from October to March. For leaf purpose, it can be grown throughout the year but during hot month (April-June) it can grow under shad.

\section{Soils and preparation of land}

As an irrigated crop, coriander can be cultivated on all types of soils, provided sufficient organic manure is applied. Black cotton soils with high retentivity of moisture are the best for coriander cultivation, the land is ploughed 3-4 times after kharif crops harvest and pre sowing irrigation done in the month of October, after soil come in tilth, then one ploughing followed by sowing of coriander in second fortnight of October.

\section{Manures and fertilizes}

If available, well rotten farmyard manure (1015 tonnes/ha) and fertilizers at the rate of 20 $\mathrm{kg}$ nitrogen, $30 \mathrm{~kg}$ Phosphorus, and $20 \mathrm{~kg}$ Potassium per hectare are applied at the time of preparation of the field before sowing for a crop in rainfed areas. In the irrigated areas, application of $\mathrm{N}$ is increased to $50 \mathrm{~kg} / \mathrm{ha}$, half of the dose of $\mathrm{N}$ and full dose of $\mathrm{P}$ and $\mathrm{K}$ is applied as basal dose and the remaining half is applied in two split one at fist irrigation (50-60 days after sowing) and second split at flowering stage of the crop.

\section{Sowing}

About $15-20 \mathrm{~kg}$ seed is required for sowing in one hectare. Seed are rubbing before sowing, as splits the seed. Seeds are germinated a little earlier than the intact fruits. Before sowing, seeds are treated with suitable fungicides like carbendazim $0.75 \mathrm{~g}+$ Thiram $1.5 \mathrm{~g}$ or Thiram $3 \mathrm{~g}$ per $\mathrm{kg}$ of seed as a preventive measure against stem-gall disease. The seeds are sown in lines at a spacing of $30 \mathrm{~cm}$ between rows and 10-15 cm between plants. Depending upon the temperature, germination takes place in about 10-15 days. 


\section{Irrigation}

Depending upon the soil and climatic conditions, irrigation is given. Generally two irrigation in addition to pre sowing irrigation is require for obtaining higher yield of coriander crop. First irrigation is give at branching stage at 50 to 60 days after sowing and second at grain filling stage 90-100 days after sowing of crop. Coriander crop are also irrigate by mini sprinkler at $12-15$ days intervals, mini sprinkler run 2.5-2.5 hours three times in a day and for ordinary sprinkler
4.5 hour per day or 1.5-1.5 hours run for three times in a day for getting higher yield from coriander crop.

\section{Intercultural}

For a good crop, weeding and hoeing is necessary. Generally one hoeing and weeding are enough for normal crop. Pre emergence application of pendimethalin at 0.75 to $1 \mathrm{~kg}$ a.i. per ha to kill emerging weeds and crop grow under weed free environment condition.

Table.1 Chemical composition of Coriander sativum seed (Diederichsen, 1996)

\begin{tabular}{ll}
\hline Component Content & Percentage (\%) \\
\hline Water & 11.37 \\
Crude protein & 11.49 \\
fat & 19.15 \\
Crude fibre & 28.43 \\
Starch & 10.53 \\
Pentosans & 10.29 \\
Sugar & 1.92 \\
Mineral constituents & 4.98 \\
Essential oil & 0.84 \\
\hline
\end{tabular}

Table.2 Composition of essential oil in seed of Coriander sativum (Diederichsen, 1996)

\begin{tabular}{lll}
\hline $\begin{array}{l}\text { Main } \\
\text { components }\end{array}$ & \% of Total Essential oil & $\begin{array}{l}\text { Minor components ( all with } \\
\text { less than 2\%)* }\end{array}$ \\
\hline Linalool & 67.7 & $\beta$ - pinene \\
$\alpha$ - pinene & 10.5 & Camphene \\
$\gamma$ - terpine & 9.0 & Myrcene \\
Geranylacetate & 4.0 & Limonene \\
Camphor & 3.0 & p-cymol \\
Graniol & 1.9 & $\begin{array}{l}\text { Dipentene } \\
\alpha \text { - terpinene } \\
\end{array}$ \\
& & n-decylaldehyde \\
& Borenol \\
\hline
\end{tabular}

\section{Diseases and pest}

Among disease, the wilt, powdery mildew, stem-rot and stem-gall are important, causing damage to the crop.

\section{Wilt disease}

Fusarium oxisporum f. Sp. coriandri is a fungus which causes wilt, affect root system of the plants. To prevent the crop from infection of 
fungus, deep ploughing should be done during summer season. Crop rotation may also be followed. In those plots, where effect of this disease has been noticed, coriander crop should not be taken for 2-3 years. Sowing should be done after seed treatment with carbendazim at $1.5 \mathrm{~g}$ per $\mathrm{kg}$ seed or Thiram $1.5 \mathrm{~g}$ per $\mathrm{kg}$ seed (Govt. of Raj., 2014 and Sharma et al., 2016)

\section{Powdery mildew}

The pathogen Erysiphe polygoni attacks on coriander plants. It appears as small, white circular patches on young parts of stems and leaves. The increases in size, often coalesce to cover extensive areas of leaf surface. Affected leaves are reduced in size and distorted. Premature sterility is also common. In serve cases, the umbels dry up. Sometimes, the seeds are attached.

Attack of this disease is seen during cloudy weather condition. White powdery growth Appears on the leaves and bunds during its primary stage. Seed formation may not take place in affected plants due to this disease. To control this disease, dusting of sulphur dust at 20-25 kg per hectare should be done. Spraying of wettable sulphur $0.25 \%$ or karathane $0.05 \%$ can also control this disease (Sharma et al., 2016 and Govt. of Raj., 2014)

\section{Stem gall}

Galls appear on the leaves and stems of the plants affected by this disease. Shape of coriander seeds change due to affect of this disease. To prevent this disease 2-3 year crop rotation should be done with non host crops. To control this disease, sowing can be done only after treating the seeds with $4 \mathrm{~g}$ Thiram and $2 \mathrm{~g}$ carbendazim per $\mathrm{kg}$ seeds.

Spray $0.1 \%$ solution of carbendazim when the symptoms start appearing and repeat the spraing spraying at an interval of 20 days till the disease is completely controlled (Sharma et al., 2016 and Govt. of Raj., 2014)

\section{Blight}

In this disease dark brown spots appears on the stem and leaves of infected plants. To control this disease spraying of $0.2 \%$ solution of Mancozeb should be used to control this disease (Sharma et al., 2016)

Among insect pest, aphids, white fly, leaf eating borer and mite are important, causing damage to the coriander crop.

\section{Aphids}

Aphids are major yield reducing factor in coriander crop. The heavy infestation of aphid on coriander occurred between Decembers to March and causes the loss of more than $50 \%$ of yield in unprotected crop. During flowering stage a population of 55-70 aphids per 5 plants could reduce yield up to $50 \%$. The population of aphids in coriander crop at more than 200 aphids per plants can reduce the yield of $2.0 \mathrm{qt}$ per ha. The maximum multiplication of aphid on coriander has found when the existed between 20-25 degree Celsius (maximum), 2-6 degree Celsius (minimum) and $60-65 \%$ relative humidity. When the aphid infestation occurs at flowering and fruiting stage, the fruits are not formed and, if they formed, they are shrivelled and of poor quality. Higher losses in yield could be caused by a small number of aphids infesting the crop at the beginning of flowering than by a large number of aphids at the grain filling stage.

To control aphid infestation on coriander crop, application of neem based commercial formulation like Neemarin at $1 \%$ and seed extract of neem (Azadirachata indica), karanj (Pongamia sp.), buken (Melia sp.) and pride of India (Lagerstroemia indica) reduce the aphids population by 50 per cent within 7 days of application (Kant et al., 2016). Spraying of Dimethoate 30 EC or Methyl demetone 25 EC 1 1 per ha before flowering can control aphid population considerably. This spray may be repeated in 10 days intervals (Govt. of Raj., 2014) 


\section{White fly}

White fly (Bemisia tabaci) a polyphagus pest found serious pest of coriander crop. Nymphs and adults of white fly causes damage the crop. They remain underside the leaves and suck the sap. Continuous sucking the sap from the leaves results in chlorotic spots and later on leaves coalesce and become brittle and finally drop down from the plant prematurely. The honey dew secreted by the pest drop on the upper surface of the lower leaves and helps in development of shooty moulds which interferes with photosynthesis of leaves (Kant et al., 2016). Spraying of Dimethoate 30 EC or Methyl demetone $25 \mathrm{EC}$ one litre per ha before flowering can control aphid population considerably. This spray may be repeated in 10 days intervals. (Govt. of Raj., 2014)

\section{Mite}

The brown wheat mite [Petrobia lateens (Muller)] was first reported feeding on coriander. It remains active during winter with peak activity in March. It is a minute, non webbing and swift moving mite and has a tendency to dislodge from the plant which disturbed. The larva, nymphs and adults feed on upper as well as the lower surface of leaves, leaf sheaths and floral parts. Infested leaves started withering from top downwards. The plants become chlorotic due to loss of cell sap, resulting in poor seed formation. Heavily infested plants show sickly yellowish or bronzing appearance (Kant et al., 2016).

\section{Reasons for low yield of coriander at farmer's fields}

Optimum sowing time is not followed due to delay in kharif crop harvest, field preparation, pre sowing irrigation etc. Sometimes non availability of quality seed or improved variety seed, farmers go for the local seed in hand. More than 90 per cent of farmers, coriander seed sown in closer spacing through tractor drawn wheat seed drill and in most of the situation the plant population at farmer's field is high or two-three times high of the recommended stand. Lack of popularization of seed cum fertilizer drill for sowing and use of inadequate and imbalance dose of fertilizers especially the phosphatic fertilizers by farmers does not make possible to fetch potential yield. The problem of aphids and stem gall cause substantial loss in the coriander crop and farmers do not adopt the adequate control measure well in time. Mechanical weed control is costly and chemical control is quite uncommon because lack of post emergence herbicide for coriander crop.

\section{Specific constraints with marginal/sub marginal farmers}

The adoption of well proven technology is constrains due to small size of holding and poor farm resources. Small and marginal farmers have less capability to take risk and do not dare to invest in the costly inputs due to high risk and the poor purchase capacity of small farmer. Traditional implements and tools are still in practice due to small holdings which have poor working efficiency. The lack of simple modern tools for small holdings also hinders the adoption of improved technologies for coriander crop in zone.

In conclusion thus, the cultivation of coriander crop with improved technologies including suitable varieties, weed management, nutrients and pest management has found more productive and remunerative in the zone, which has high potential in coriander production, processing and export. The present literature supports the potential of Coriander as a medicinal and Pharmacological importance. In view of the nature of the plant, more research can be done to investigate the unexplored and unexploited potential of this crop in humid south eastern plains zone of Rajasthan

\section{References}

Basilico, M. Z. and Basilico, J. C. 1999. Inhibitory effects of some spice essential pols on Aspergillus ochraceus 
NRRL 3174 growth and ochratoxin aproduction. Lett Appl Microbiol 29:238-241

Dimri, B. R.; Khan, M. N. A and Narayana, M. R. 1976. Some promising selections of Bulgarian coriander (Coriandrum sativum L.) for seed and essential oil with a note on cultivation and distillation of oil. Indian Perfumer 20: 13-21

Ertas, O. N.; Guler, T., Cftc, M., Dalklc, B. and Ylmaz, O. 2005. The effect of a dietary supplement coriander seeds on the fatty acid composition of breast muscle in Japanese quail. Revue-de-Medecine Veterinaire 156:514-518

Govt. of Raj., 2014. Rabi crops Package book of Zone V.

Handa, S. S. and M. K. Kaul. 1996. Supplement to cultivation and utilization of medicinal plant, National Institute Of science communication, Regional research laboratory (CSIR), JammuTavi, India. : 818.

Janardhanan, M and Thoppil, J. E. 2004. Herb and spice essential oils. Discovery Publishing House, New Delhi- 110002. Pp. 40-42

Kant, K.; Meena, N.K. and Meena, S. R. 2016. Important insect pests of seed spices and their management. Sustainable Production of seed spices under changing climate scenario. NRCSS, Ajmer, Rajasthan. Pp.81-84

Nagar, R. K.; Meena, B. S. and Dadheech, R. C. 2009. Effect of integrated weed and weed and nutrient management on density, productivity and economics of coriander (Coriandrum sativum). Indian Journal of Weed Science 41(1\&2):71-75
Pascual and Villalobos, M. J. 2003.Volatile activity of plant essential oils against stored product beetle pests. Advances in stored product protection. Proceeding of $8^{\text {th }}$ International Working Conference on Stored Product Protection, $C A B$ International, Wallingford: UK 648-650

Pathak, N. L.; Kasture, S. B., Bhatt, N. M. and Rathod, J. $\quad$ D. 2011. Phytopharmacological Properties of Coriander Sativum as a Potential Medicinal Tree: An Overview. Journal of Applied Pharmaceutical Science 01 (04): 20-25

Saxena, S. N. and Rathore, S.S. 2016. Bioactive compounds in seed spices and their medicinal potential. Sustainable Production of seed spices under changing climate scenario. NRCSS, Ajmer, Rajasthan. Pp.112-121

Saxena, S. N.; Sharma, Y. K., Rathore, S. S.; Singh, K. K.; Barnwal, P.; Saxena, R.; Upadhyaya, P. And Anwer, M.M. 2015. Effect of cryogenic grinding on volatile oil, oleoresin content and anti-oxidant properties of coriander (Coriandrum satum L.) genotypes. Journal of Food Science Technology 52 (1):568-573

Sharma, Y.K.; Meena, R.D. and Meena, N.K. 2016. Major diseases and their management in seed spices. Sustainable Production of seed spices under changing climate scenario. NRCSS, Ajmer, Rajasthan. Pp.78-80

Tiwary, R.S. and Agarwal, A. 2004. Production technology of spices. $1^{\text {st }}$ ed. International Book Distribution Co. Chaman studio buildibg, $2^{\text {nd }}$ floor, charbagh, Lucknow, 2260004 UP, India. Pp. 254-271

\section{How to cite this article:}

Bairwa, R.K., B.L. Dhaka, M.K. Poonia, B.L. Nagar and Balai, C.M. 2017. Coriander a Potential Seed Spice Crop of Humid South Eastern Plains Zone of Rajasthan-A Review Article. Int.J.Curr.Microbiol.App.Sci. 6(4): 2385-2391. doi: https://doi.org/10.20546/ijcmas.2017.604.278 